\title{
Integrative taxonomy of a new species of planarian from the Lake Ohrid basin, including an analysis of biogeographical patterns in freshwater triclads from the Ohrid region (Platyhelminthes, Tricladida, Dugesiidae)
}

\author{
Giacinta Angela Stocchino ${ }^{1, \dagger}$, Ronald Sluys ${ }^{2, \ddagger}$, Paolo Deri ${ }^{3, \S}$, Renata Manconi ${ }^{1,1}$
}

I Department of Science for Nature and Environmental Resources, Via Muroni 25, I-07100, University of Sassari, Sassari, Italy 2 Naturalis Biodiversity Center, P.O. Box 9514, 2300 RA Leiden, The Netherlands 3 Department of Biology, S.S. 12 Abetone e Brennero 4, I- 56127, University of Pisa, Pisa, Italy

† urn:lsid:zoobank.org:author:A23390B1-5513-4F7B-90CC-8A3D8F6B428C

† urn:lsid:zoobank.org:author:8COB31AE-5E12-4289-91D4-FF0081E39389

§ urn:lsid:zoobank.org:author:DDECB6E7-D540-4739-A796-742BDBFE2865

| urn:lsid:zoobank.org:author:ED7D6AA5-D345-4B06-8376-48F858B7D9E3

Corresponding author: Giacinta Angela Stocchino (stocchin@uniss.it)

Academic editor: Lyubomir Penev | Received 19 April 2013 | Accepted 20 June 2013 | Published 28 June 2013

urn:lsid:zoobank.org:pub:B61969DE-DB12-4C74-8299-859F5E05568E

Citation: Stocchino GA, Sluys R, Deri P, Manconi R (2013) Integrative taxonomy of a new species of planarian from the Lake Ohrid basin, including an analysis of biogeographical patterns in freshwater triclads from the Ohrid region (Platyhelminthes, Tricladida, Dugesiidae). ZooKeys 313: 25-43. doi: 10.3897/zookeys.313.5363

\begin{abstract}
A new species of the genus Dugesia is described from the Lake Ohrid region in the western part of the Balkan Peninsula, forming the first fully documented species description for this genus in the Ohrid area. The morphological species delimitation is supported by complementary molecular, karyological, and cytogenetic data available from the literature. Therefore, species delineation is based on a truly integrative approach. Further, a short account on the degree of freshwater planarian endemicity in the Ohrid region is provided.
\end{abstract}

\section{Keywords}

Platyhelminthes, Tricladida, Dugesia, integrative taxonomy, ancient lake, Ohrid, new species, endemicity

Copyright Giacinta Angela Stocchino et al. This is an open access article distributed under the terms of the Creative Commons Attribution License 3.0 (CC-BY), which permits unrestricted use, distribution, and reproduction in any medium, provided the original author and source are credited. 


\section{Introduction}

The oligotrophic karstic Lake Ohrid is located in the western part of the Balkan Peninsula on the Macedonian-Albanian frontier. With a limnological age of 2-5 million years it is considered to be one of the oldest lakes in Europe (Albrecht and Wilke 2008). The lake is characterized by a high degree of biodiversity and endemicity in several groups of organisms (Stanković 1960, Albrecht and Wilke 2008). With more than 210 known endemic species it is probably the most biodiverse lake in the world, at least when one takes surface area into account (Albrecht and Wilke 2008). Due to its peculiarities, Lake Ohrid is considered to be a key site for biodiversity and speciation research (Albrecht and Wilke 2008).

The first studies on the triclad fauna of the Ohrid area date back to the 1920's with the first description of several new species of Phagocata Leidy, 1847 and Dendrocoelum Örsted, 1844 (cf. Stanković and Komárek 1927). Further important researches carried out during the 20th century, mainly by Stanković $(1938,1960,1969)$ and Kenk (1978), contributed to a better knowledge of this very interesting planarian fauna. In his valuable monograph, Stanković (1960) in particular pointed out the extraordinary biogeographical situation of the endemic triclads in the Ohrid region.

In this paper we report on a new species of freshwater planarian of the genus $D u$ gesia, forming the first fully documented species description for this genus in the Ohrid area. Our morphological species delimitation was supported by complementary molecular, karyological, and cytogenetic data available from the literature. Therefore, our species delineation is based on a truly integrative approach. Further, we provide a short account on the biogeographical patterns in freshwater planarians and their degree of endemicity in the Ohrid region.

\section{Materials and methods}

Planarians were collected in 1995 from the southern section of Lake Ohrid basin, near the town of Çërravë, along the Pogradec-Korçë road, ca. $10 \mathrm{~km}$ south-east of Pogradec, at an altitude of ca. $800 \mathrm{~m}$ asl (Fig. 1). The animals were found under pebbles and among vegetation in a rivulet, flowing along a steep meadow, joining a tributary stream of the lake. All individuals $(\mathrm{n}=20)$ were asexual at collection. The collected specimens were transferred to the laboratory, reared in glass bowls under semi-dark conditions at $18+/-2{ }^{\circ} \mathrm{C}$ and fed with fresh beef liver.

After having been kept in the laboratory for about one year, during which the strain notably increased in numbers due to asexual reproduction by fission, approximately $30 \%$ of the specimens shifted from the fissiparous reproductive mode towards a tendency to sexualize, i.e. to develop reproductive organs. These sexualized animals displayed the characteristic features of ex-fissiparous individuals: large body size, development of the copulatory apparatus, hyperplasic ovaries. 
For morphological study sexualized specimens were fixed for 24 hours in Bouin's fluid, dehydrated in a graded ethanol series, cleared in toluene, and embedded in synthetic paraffin. Serial sections were made at intervals of 5-7 $\mu \mathrm{m}$ and were stained with Harris' haematoxylin-eosin, Mallory's trichrome, or Pasini's reagent.

The material is deposited in the Naturalis Biodiversity Center, Leiden, The Netherlands (collection code: ZMA), and in the Giacinta A. Stocchino collection (CGAS), University of Sassari.

\section{Abbreviations used in the figures}

bc: bursal canal; bg: bulb glands; ca: common atrium; cb: copulatory bursa; cg: cement glands; cm: circular muscles; d: diaphragm; e: epithelium; ed: ejaculatory duct; g: gonopore; gd: gonoduct; ie: infranucleate epithelium; l: lumen; lm: longitudinal muscles; lod: left oviduct; ma: male atrium; pb: penis bulb; pf: penial fold; pg: penis papilla glands; ph: pharynx; pp: penis papilla; rod: right oviduct; s: spermatophore; sg: shell glands; sv: seminal vesicle; vd: vas deferens.

\section{Results}

\section{Systematic Account}

Order Tricladida Lang, 1884

Suborder Continenticola Carranza, Littlewood, Clough, Ruiz-Trillo, Bagunà \& Riutort, 1998

Family Dugesiidae Ball, 1974

Genus Dugesia Girard, 1850

\section{Dugesia superioris Stocchino \& Sluys, sp. $\mathrm{n}$.} urn:Isid:zoobank.org:act:E1A595E2-6466-4F59-99CF-3E846A545332 http://species-id.net/wiki/Dugesia_superioris

Figs 1-4; Table 1

Material examined. Holotype: ZMA V.Pl. 7153.1, Çërravë, Pogradec District (4050'56"N, 2042'60"E), Lake Ohrid basin, Albania, August 1995, coll. P. Deri and N. Mazniku, one set of sagittal sections on 50 slides (stained in Harris' haematoxylin-eosin).

Paratypes: CGAS Pla 6. 1, ibid., sagittal sections on 43 slides (stained in Harris' haematoxylin-eosin); CGAS Pla 6. 2, ibid., sagittal sections on 12 slides (stained in Mallory's trichrome); CGAS Pla 6. 3 ibid., transverse sections on 135 slides (stained in Pasini's reagent); ZMA V.Pl. 7153.2, ibid., transverse sections on 131 slides (stained in Harris' haematoxylin-eosin); CGAS Pla 6. 4, ibid., transverse sections on 60 slides 

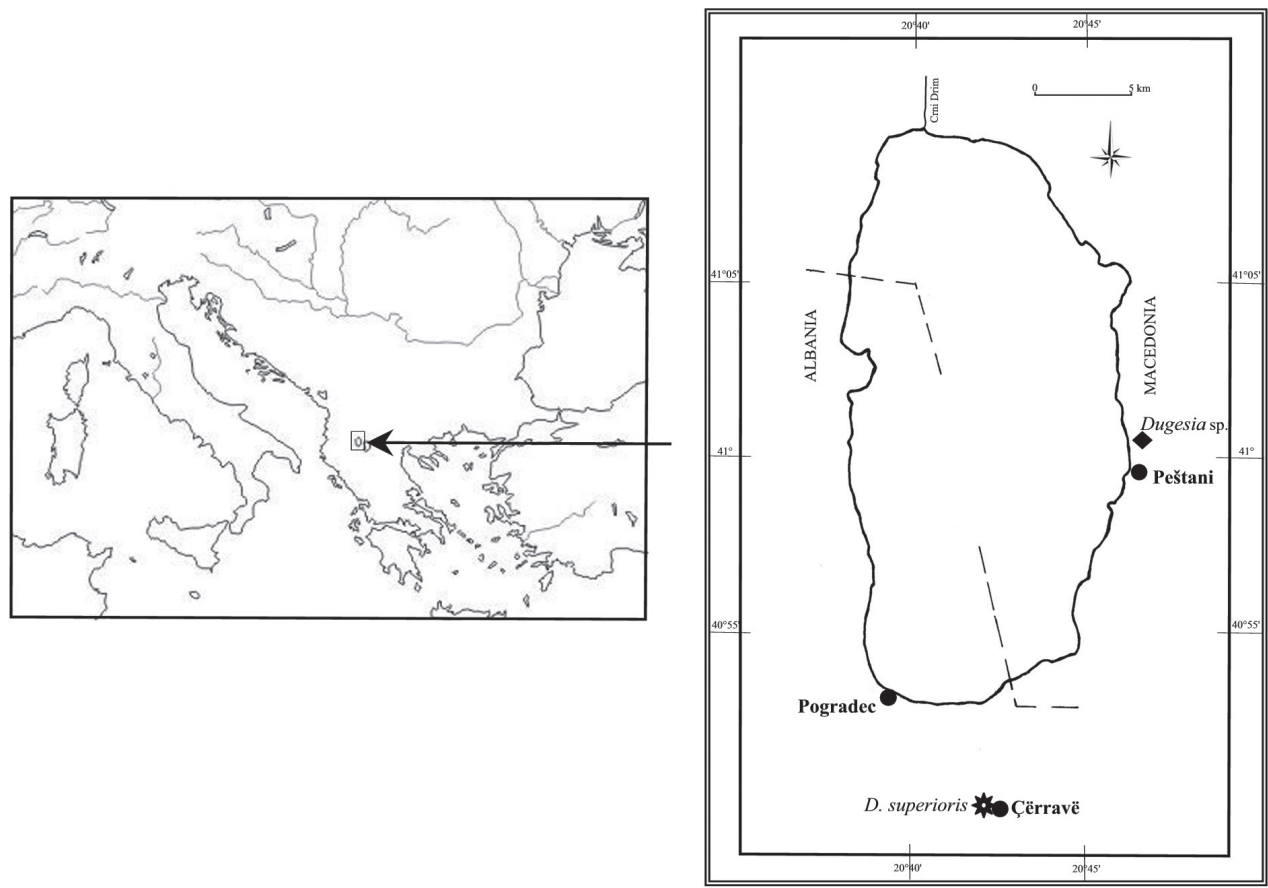

Figure I. Geographic distribution of Dugesia superioris (indicated by an asterisk) and Dugesia sp. NMNH 55294 (indicated by black diamond) in the Lake Ohrid region.

(stained in Harris' haematoxylin-eosin); ZMA V.Pl. 7153.3, ibid., horizontal sections on 21 slides (stained in Harris' haematoxylin-eosin).

Diagnosis. Dugesia superioris is characterized by the presence of the following features: dorsal course of the ejaculatory duct; subterminal opening of the ejaculatory duct; asymmetrical openings of the oviducts into the bursal canal; openings of vasa deferentia at halfway along the seminal vesicle; plump penis papilla; small diaphragm; triploid chromosome complement of $24+1 \mathrm{~B}$-chromosomes.

Description. Body size of living fissiparous specimens ranged from 7-10 $\mathrm{mm}$ in length and $1.5-2 \mathrm{~mm}$ in width (Fig. 2). Sexualized specimens were about $13-16 \mathrm{~mm}$ in length and about $3 \mathrm{~mm}$ in width. Two eyes are present in the middle of the head, and unpigmented auricular grooves are marginally placed just posteriorly to the eyes. The colour is uniformly brown dorsally, and pale ventrally.

Inner and outer pharyngeal musculature is bilayered, i.e. without an extra, third, outer longitudinal muscle layer. The ovaries are hyperplasic, with several scattered masses at a short distance behind the brain, filling up the entire dorso-ventral space. A degenerative condition is clearly evident in the ovaries, in that maturation of the oocytes is regular up to the beginning of the diplotene stage, whereas diplotenic oocytes show progressive cytoplasm vacuolation, followed by collapse of the entire cell content and by cell necrosis. 


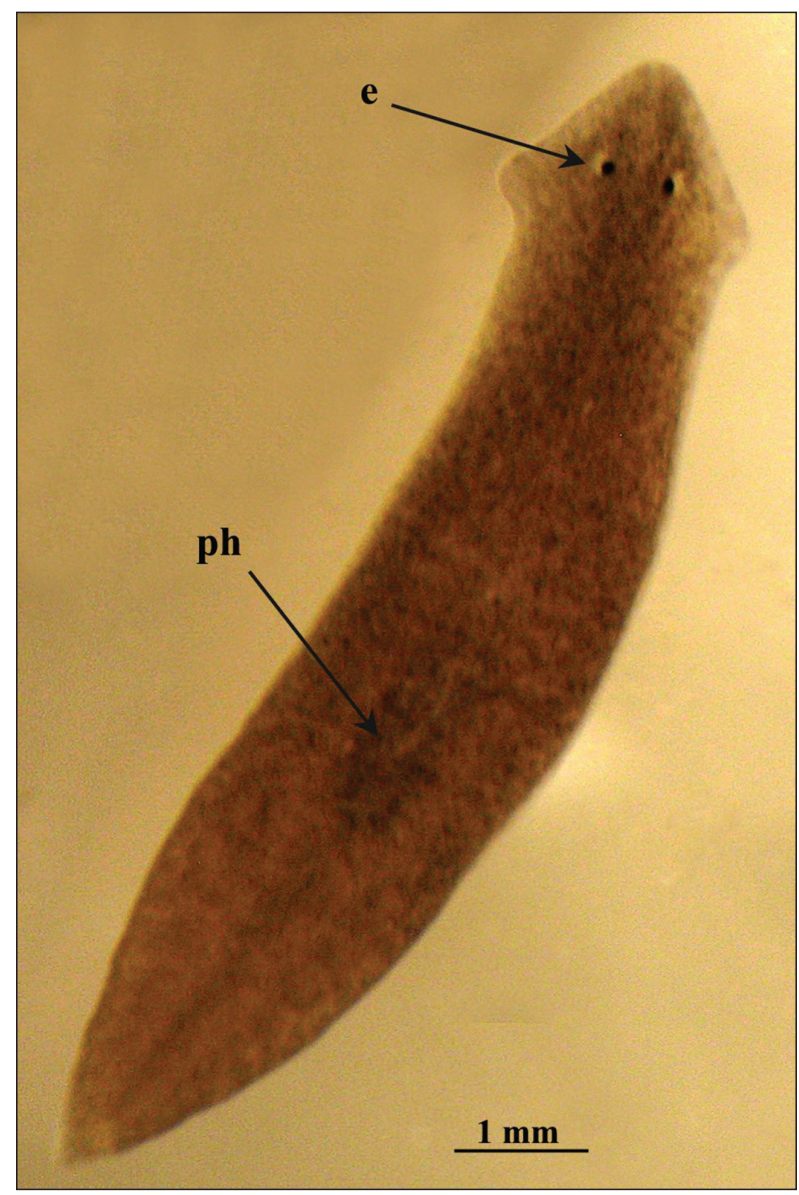

Figure 2. Dugesia superioris. Habitus of a living fissiparous specimen.

The anterior portion of the infranucleated oviducts is expanded to form a seminal receptacle that arises in the middle of the ovarian masses at a poorly defined position, dependent upon the hyperplasic condition of the ovaries. The oviducts run ventrally in a caudal direction up to the vaginal area and open asymmetrically into the distal section of the bursal canal. The right oviduct opens dorsally to the left one. The latter opens very close to the point where the canal communicates with the common atrium (Fig. 3). The very abundant shell glands open at the level of the left oviducal opening.

The testes are situated dorsally and extend from just anterior to the ovaries to the posterior end of the body. The testes generally are under-developed in that the majority of germ cells are represented only by spermatogonia (ca. 90\%). In only some specimens, and then in only a few follicles, mature sperms are present. However, in all cases anomalies were observed, such as irregularly shaped spermatids and spermatozoa. Vitellaria are located between the testes and the intestinal branches. 


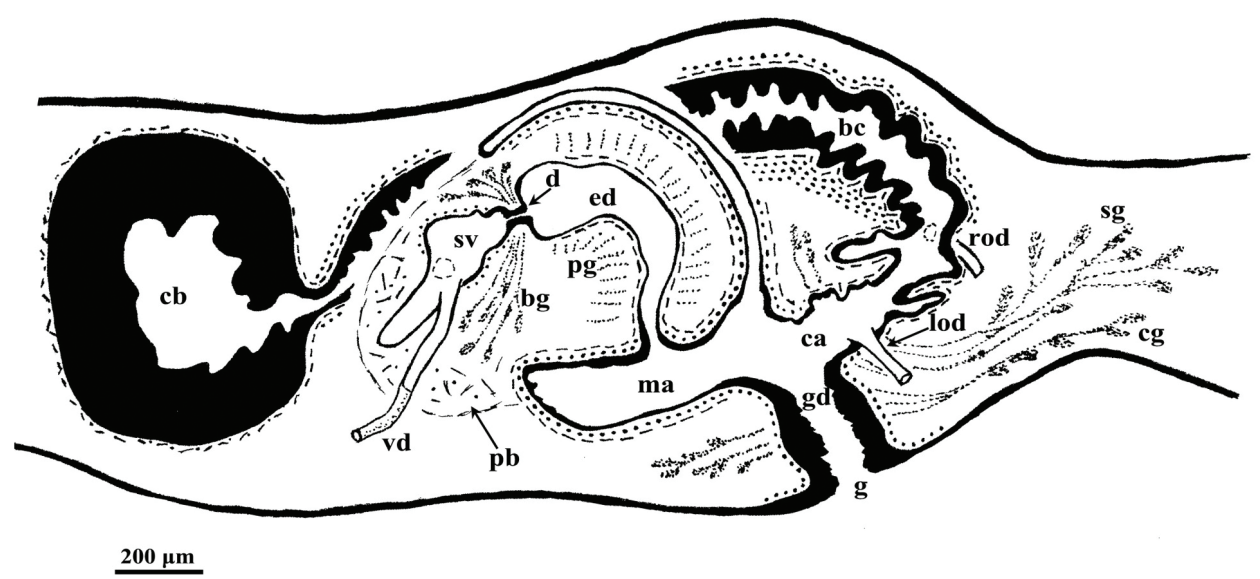

Figure 3. Dugesia superioris. Holotype ZMA V.Pl. 7153.1, sagittal reconstruction of the copulatory apparatus (anterior to the left).

The large sac-shaped copulatory bursa is lined by a columnar, glandular epithelium bearing basal nuclei and it is surrounded by a thin layer of muscles. From the midposterior wall of the bursa the bursal canal runs in a caudal direction, to the left of the copulatory apparatus. Posteriorly to the gonopore the bursal canal recurves anteroventrally and, subsequently, opens into the posterior section of the atrium. The bursal canal is lined by a pleated epithelium with cylindrical, infranucleated, and ciliated cells and is surrounded by a thin, subepithelial layer of longitudinal muscles, followed by a thicker layer of circular muscle. Ectal reinforcement is absent (Figs 3, 4C). At its distal section, near the atrium, the bursal canal shows several deep folds.

The moderately developed penis bulb, rich in glands, consists of intermingled longitudinal and circular muscle fibres. It houses an elongated seminal vesicle, which extends through the entire length of the penis bulb. The anterior half of the seminal vesicle is tubular in shape, while its distal, posterior section is considerably expanded.

The vasa deferentia penetrate the antero-lateral wall of the penis bulb and open separately and symmetrically into the seminal vesicle at a position about halfway along the vesicle. No spermiducal vesicles were observed in any of the specimens examined. The seminal vesicle, lined with a flat epithelium and surrounded in its distal, posterior section by layers of circular muscle fibres, opens into the ejaculatory duct via a small diaphragm. The latter, located at the base of the penis papilla, receives the openings of very abundant bulb glands. The blunt penis papilla is lined with an infranucleated epithelium that is underlain with a thin subepithelial layer of circular muscles fibres, followed by a layer of longitudinal muscle fibres.

The ejaculatory duct follows a dorsally displaced course through the penis papilla and has a sub-terminal opening. The spacious lumen of the ejaculatory duct is lined by a cuboidal, infranucleated epithelium that is surrounded by a layer of longitudinal muscles and receives the abundant secretion of penis papilla glands; in the majority 

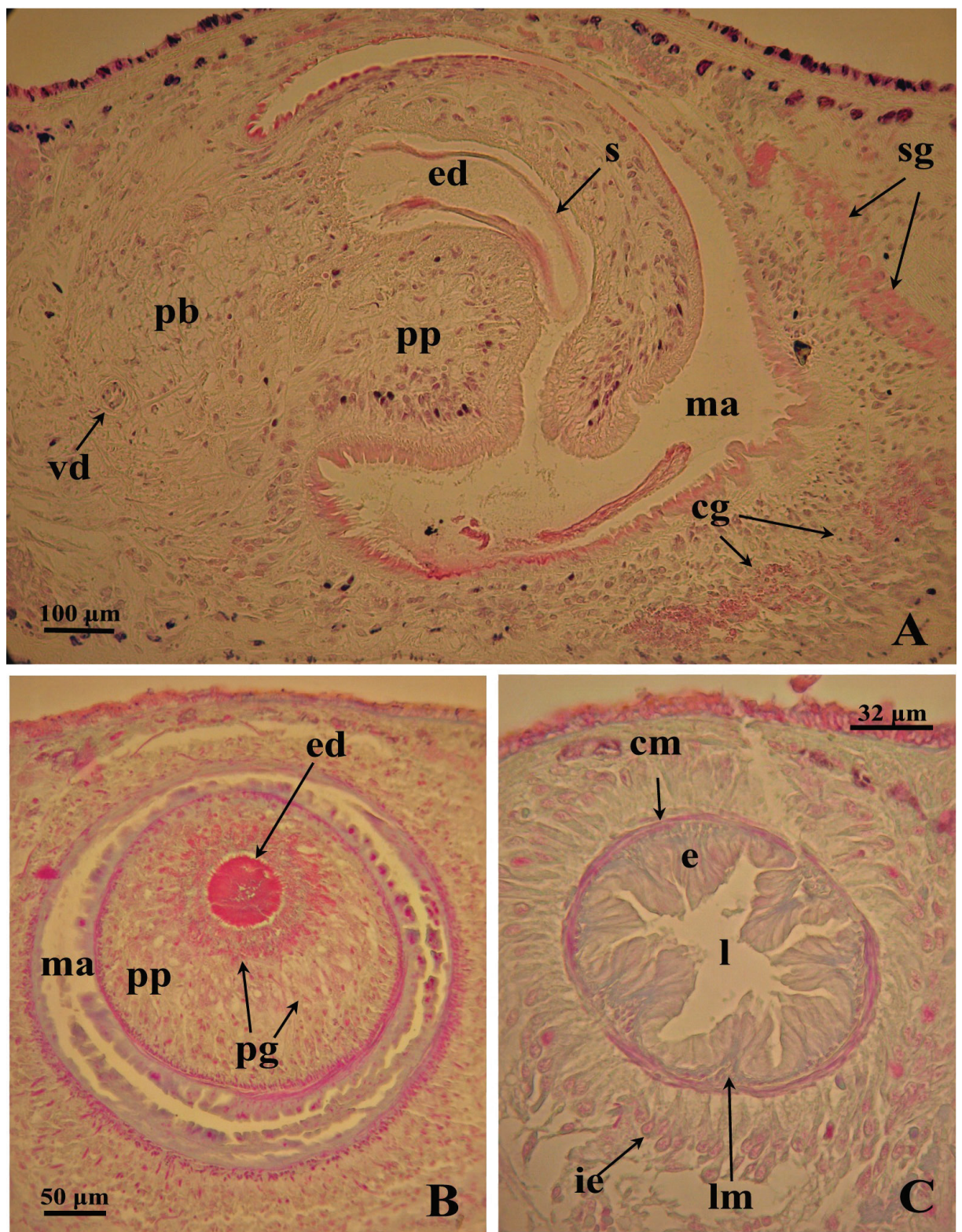

Figure 4. Dugesia superioris. Photomicrographs of the copulatory apparatus. A Holotype ZMA V.Pl. 7153.1, sagittal section showing the penis bulb and the penis papilla with the ejaculatory duct B Paratype CGAS Pla 6. 3, transverse section of the penis papilla and the ejaculatory duct surrounded by numerous glands C Paratype CGAS Pla 6. 3, transverse section of the bursal canal.

of examined specimens the ejaculatory duct contained an empty spermatophore (Fig. $4 \mathrm{~A}, \mathrm{~B})$. Both the bulb glands and the penis papilla glands secrete globules that stain purple in Pasini's reagent (Fig. 4B). The acentral, dorsally displaced ejaculatory duct 
makes the penis papilla asymmetrical, with the ventral part being thicker than the dorsal one (Figs 3, 4A,B).

The genital atrium is lined by an infranucleated epithelium that is underlain by a subepithelial layer of circular muscle, followed by a layer of longitudinal muscle fibres. The common atrium communicates with a gonoduct that is lined by a columnar epithelium, which receives the openings of very abundant cement glands; the gonoduct communicates with the ventral gonopore (Fig. 3).

Etymology. The specific epithet is derived from the Latin superius, located at a higher position, and alludes to the dorsally displaced course of the ejaculatory duct in the penis papilla.

Geographical distribution. Known from the type locality and, most likely, also from a second Albanian locality, viz. Voskopojë (see below).

\section{Additional data supporting the status of the new species}

A karyological study by Deri et al. (1999) identified for the Pogradec population a complement of 24 standard chromosomes with one B-chromosome, suggesting a triploid condition with a haploid number of $n=8$. Moreover, their karyometric analysis indicated a probably aneutriploid condition, due to a constant excess of small, medium-sized chromosomes. A haploid number with $n=8$ represents the most common chromosome number among Dugesia species. Dugesia superioris shares the triploid condition with a haploid number of $\mathrm{n}=8$ with only a few other species from the Western Palaearctic Region, viz. D. benazzii Lepori, 1951, D. etrusca Benazzi, 1946, D. liguriensis De Vries, 1988a, and D. subtentaculata (cf. Benazzi and Benazzi-Lentati 1976, Ribas 1990, Pala 1993, cf. Lázaro et al. 2009).

A molecular cytogenetic comparison of several species and populations of the genus Dugesia revealed that these planarians from Pogradec besides two telomeric NOR loci, also have a ribosomal site located in an intercalated position on the long arm of one of the largest chromosomes (Batistoni et al. 1999). This peculiar condition differs from other planarian taxa, in which $18 \mathrm{~S}+28 \mathrm{~S}$ rRNA genes appeared preferentially located on telomeric regions of medium-sized chromosomes, and was interpreted by the authors as a structural chromosomal rearrangement, such as a paracentric inversion, suggesting a case of speciation.

More recently, a phylogeographic analysis of two Albanian populations, one from Pogradec and the other from Voskopojë (populations 30 and 31, respectively in Lázaro et al. 2009), revealed that they belong to the same clade, which is well-separated from other species and populations of Dugesia in the Western Mediterranean region, thus pointing to a new species (Lázaro et al. 2009). In a second study, which included other and more eastern Mediterranean species of Dugesia, the population from Pogradec (population 15 in Solà et al. 2013) also sat on its own branch, separate from all other populations of Dugesia examined. 


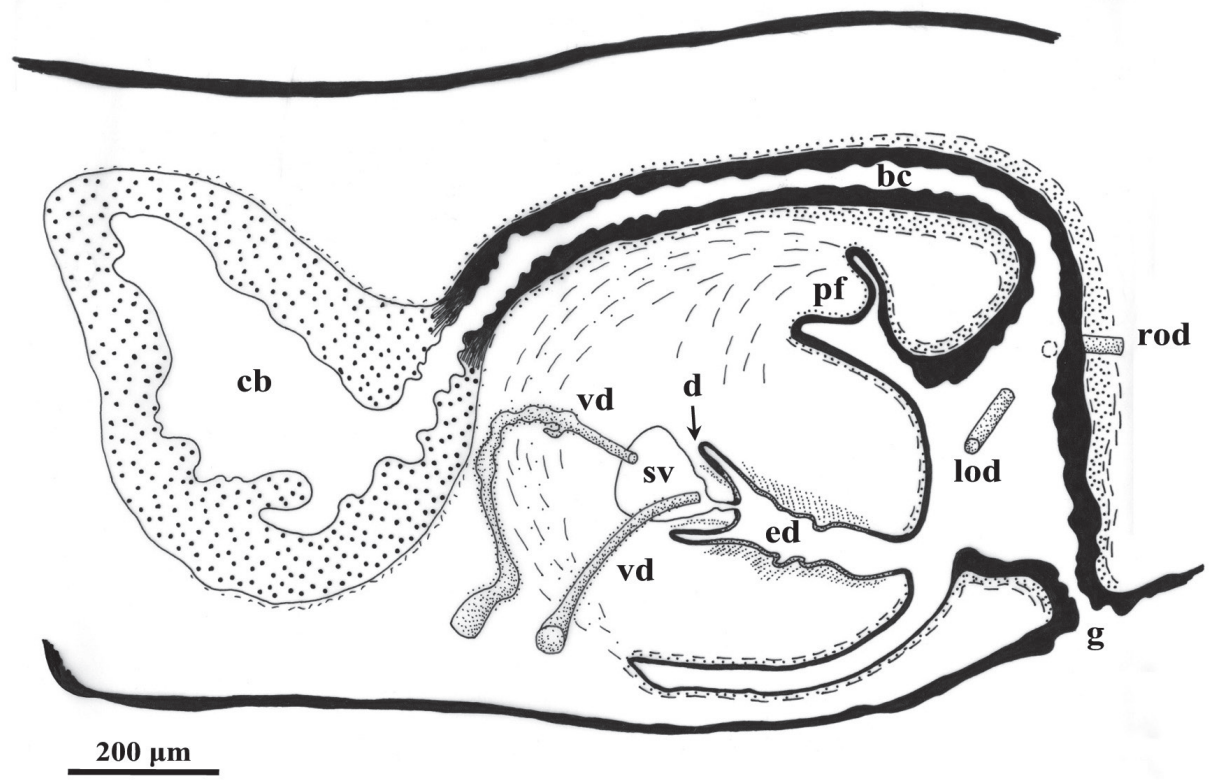

Figure 5. Sagittal reconstruction of the copulatory apparatus of Dugesia specimen NMNH 55294.

\section{Previous records of Dugesia from the Lake Ohrid region}

From Lake Ohrid only one species of Dugesia has been reported until now, viz. D. gonocephala. Stanković (1960) reported the species from running waters and springs in the Ohrid region, but he did not mention exact localities. However, in view of the fact that in that period all continental European planarians with a triangular head were assigned to this species, the taxonomic status of these Ohrid planarians remains uncertain. Kenk (1978) reported the presence of D. gonocephala in the Spring Elešec, about $2 \mathrm{~km}$ north of Peštani (Fig. 1). Re-examination of his material (NMNH 55294) revealed that the male copulatory apparatus of the animal consists of a stubby penis papilla, provided with a small, dorsal penial fold (Fig. 5). The diaphragm is rather large and pointed and projects into a broad, central ejaculatory duct, which opens at the tip of the penis papilla. The vasa deferentia open into an intrapenial seminal vesicle, albeit that the precise location of the openings is different. One vas deferens opens close to the diaphragm, whereas the other duct opens through the anterior lining epithelium of the seminal vesicle. A large copulatory bursa is situated immediately behind the pharyngeal pocket. The bursal canal is lined with a tall, nucleated epithelium and is surrounded by a subepithelial layer of longitudinal muscles, followed by a layer of circular muscle. In the vaginal area and on the posterior, curved section of the bursal canal the circular muscle layer is welldeveloped but becomes gradually thinner on the remaining part of the canal. Ectal reinforcement in the form of an extra, outer layer of longitudinal muscle is present 
in the vaginal region of the bursal canal. The oviducts open into the most proximal section of the bursal canal, one oviducal opening at the point where the canal communicates with the atrium, while the opening of the other oviduct is located somewhat more dorsally. Shell glands could not be discerned.

\section{Biogeographical patterns of freshwater triclads in the Ohrid region}

Out of a total of 27 nominal species of triclads reported from the Lake Ohrid region, 19 are endemic to this area (70\% of endemicity) (Table 1). Most of these endemics (15) are restricted to the lake proper: Dendrocoelum albidum Kenk, 1978, D. cruciferum (Stanković, 1969), D. decoratum Kenk, 1978, D. dorsivittatum Kenk, 1978, D. komareki (Stanković, 1969), D. lacustre (Stanković, 1938), D. lychnidicum (Stanković, 1969), D. magnum (Stanković, 1969), D. minimum Kenk, 1978, D. ochridense (Stanković \& Komárek, 1927), D. sinisai Kenk, 1978, D. translucidum Kenk, 1978, Phagocata maculata (Stanković, 1938), P. stankovici (Reisinger, 1960), P. undulata (Stanković, 1960). The species that live in the lake may inhabit only one of the three major bathymetrical zones of the lacustrine bottom (littoral, sublittoral and profundal) or can be found in two or more zones (Table 1). Only three species are endemic both to the lake and adjacent water systems: Dendrocoelum maculatum (Stanković \& Komárek, 1927), D. sanctinaumi (Stanković \& Komárek, 1927), Phagocata ochridana (Stanković \& Komárek, 1927).

Dendrocoelum lacteum (Müller, 1774) is a species with a very large distributional range across the Palaearctic Region that occurs both in the lake and in surrounding waters. Sywula et al. (2006) showed that D. lacteum from Lake Ohrid is genetically distant from the Central European populations and suggested that the Ohrid population should be considered as a distinct species. However, this study was based only on allozyme data, while its results do not fully support the conclusion of the authors. For example, the genetic distance between the Ohrid population of D. lacteum and D. adenodactylosum (Stanković \& Komárek, 1927) is of the same order of magnitude as the distance to the Central European populations, whereas in the phylogenetic trees the Ohrid population strongly clusters with $D$. adenodactylosum.

Dendrocoelum adenodactylosum is very common in the lake, in its tributary streams and springs and also in Lake Prespa, a nearby lake southeast of Lake Ohrid that is a major water supplier for the latter. Six species are found in surrounding streams and springs and do not occur in the lake proper, viz. Dugesia superioris, Dendrocoelum jablanicense (Stanković \& Komárek, 1927), Schmidtea lugubris (Schmidt, 1861), Crenobia alpina montenigrina (Mrázek, 1904), Planaria torva (Müller, 1774), and Polycelis tenuis Ijima, 1884. Dendrocoelum jablanicense is endemic of the Lake Ohrid region, while the others concern widespread species. 


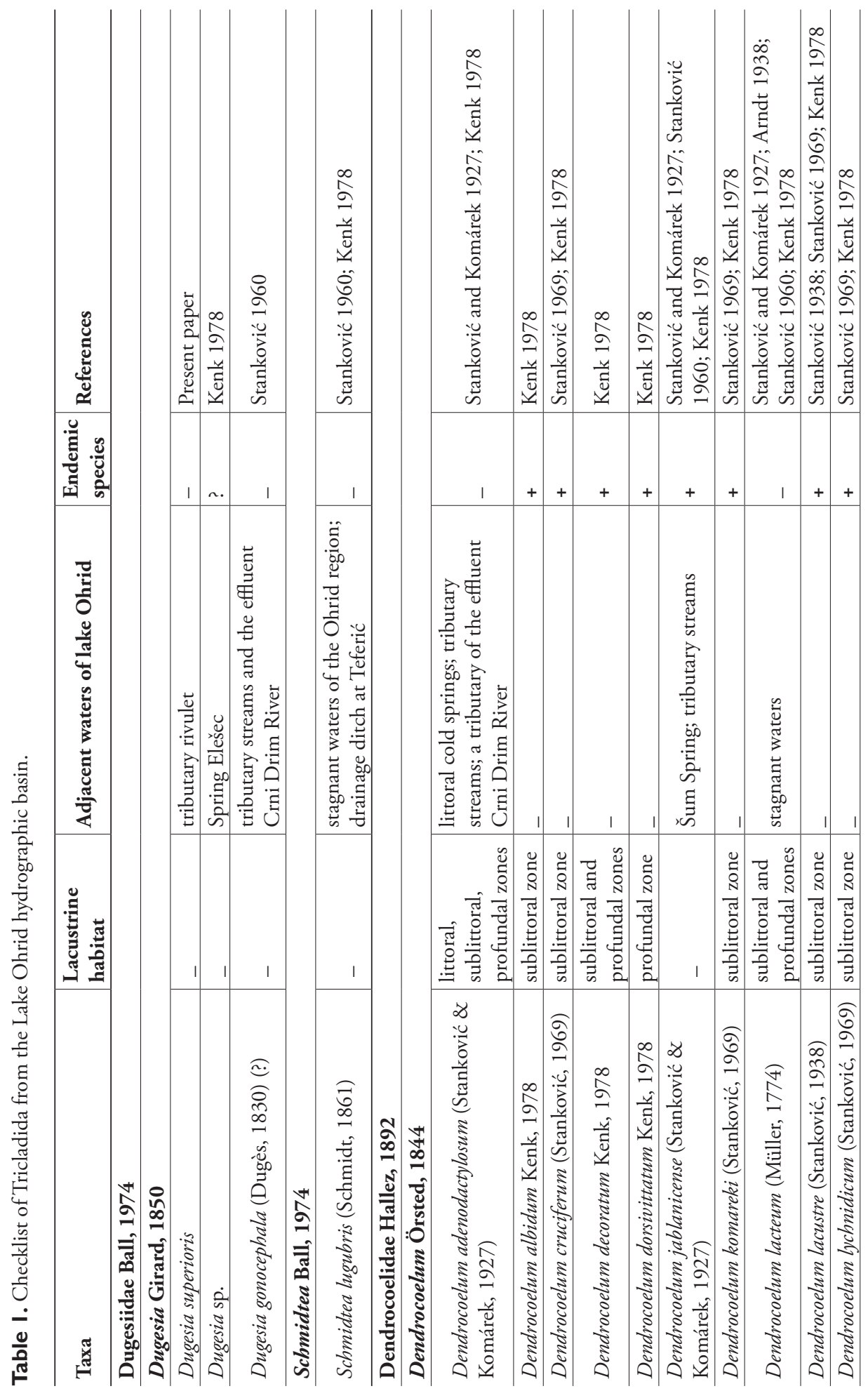




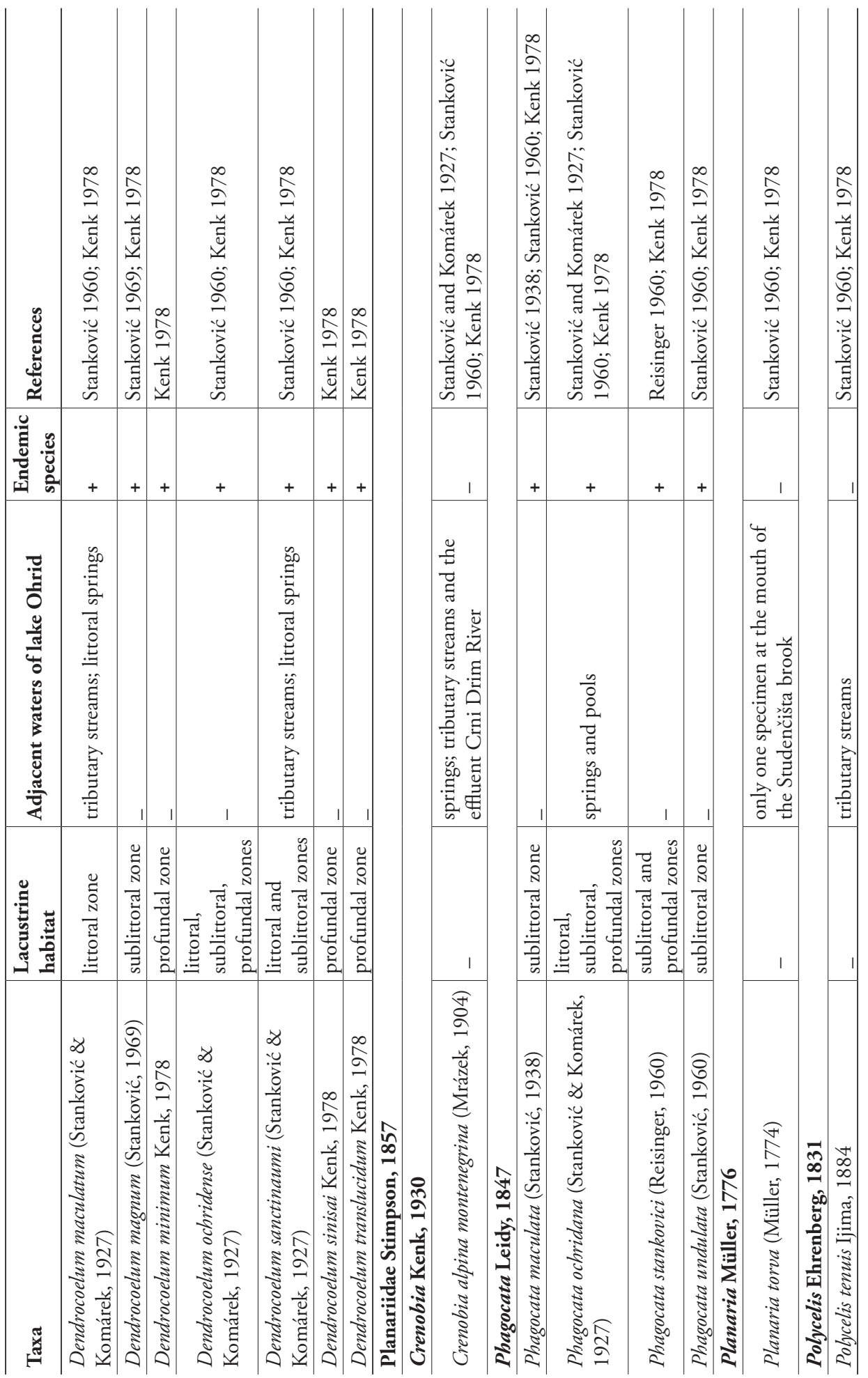




\section{Discussion}

Dugesia superioris differs from its congeners in particular in (a) the dorsal course of the ejaculatory duct, with its sub-terminal opening, (b) the asymmetrical openings of the oviducts into the bursal canal, and (c) the openings of vasa deferentia at about halfway along the seminal vesicle.

For the genus Dugesia a dorsal course of the ejaculatory duct was reported for the first time by Stocchino et al. (2005) for the endemic Sardinian species D. hepta Pala, Casu \& Vacca 1981. However, in this species the opening of the duct is located laterally on the right side, near the tip of the penis papilla. Moreover, this species is characteri-zed by a ventro-lateral penial fold, which is absent in the new species. Dugesia superioris therefore represents the second species of the genus showing a dorsal course of the ejaculatory duct. Further, another important difference between $D$. hepta and $D$. superioris is the haploid chromosome number, which counts $\mathrm{n}=7$ in the former (Pala et al. 1981) and $\mathrm{n}=8$ in the latter (Deri et al. 1999, see below).

A subterminal opening of the ejaculatory duct, as found in D. superioris, occurs in no less than 26 species of Dugesia: D. bakurianica Porfirjeva, 1958, D. biblica Benazzi \& Banchetti, 1972, D. leporii Pala et al., 2000, and D. sicula Lepori, 1948, from the Western Palaearctic; D. aethiopica Stocchino et al., 2002, D. arabica Harrath \& Sluys, 2013, D. astrocheta Marcus, 1953, D. lanzai Banchetti \& Del Papa, 1971, D. lamottei De Beauchamp, 1952, D. neumanni (Neppi, 1904) and D. myopa De Vries, 1988b from the Afrotropical Region; the other 15 species are distributed in the Oriental Region, Eastern Palaearctic and Australasian Region, viz. D. andamanensis (Kaburaki, 1925), D. austroasiatica Kawakatsu, 1985, D. batuensis Ball, 1970, D. bengalensis Kawakatsu, 1983, D. burmanensis (Kaburaki, 1918), D. deharvengi Kawakatsu \& Mitchell, 1989, D. indica Kawakatsu, 1969, D. indonesiana Kawakatsu, 1973, D. japonica Ichikawa \& Kawakatsu, 1964, D. leclerci Kawakatsu \& Mitchell, 1995, D. lindbergi De Beauchamp, 1959, D. nannophallus Ball, 1970, D. novaguineana Kawakatsu, 1976, D. tamilensis Kawakatsu, 1980, and D. uenorum Kawakatsu \& Mitchell, 1995. However, in all of these species the ejaculatory duct is ventrally displaced, except for $D$. bakurianica in which the ejaculatory duct is central. Therefore, a dorsal course of the ejaculatory duct and a subterminal opening of the duct represents a new diagnostic combination in the genus Dugesia.

The Pogradec population had already been subjected to karyological, cytogenetic, and phylogeographic studies before anything was known about the anatomy of the specimens (see above). All of these analyses pointed to a situation that this Dugesia population differs considerably from congeneric populations. Therefore, it was unsurprising that the anatomy of the Pogradec animals suggested also that they represent a new species. As a result of the cumulation of the evidences from these independent datasets, the present delineation of the new species is based on a truly integrative approach to taxonomy.

Studies on the phylogeny of Dugesia (Sluys et al. 1998 and references therein) considered the asymmetrical penial papilla to constitute an important taxonomic feature. 
However, this asymmetry related to the apomorphic presence of a ventral ejaculatory duct. Our present study shows that in future analyses this asymmetry needs to be specified by adding a third character state to character (1) (Sluys et al. 1998, p. 277 and Table II), i.e. ejaculatory duct located dorsally.

An asexual population of Dugesia sp. was collected in 2006 by R. Manconi from Voskopojë, an Albanian locality situated south-west of Lake Ohrid. Unfortunately, we have been unable to ascertain the taxonomic status of this population due to the lack of sexual specimens (Stocchino and Manconi, pers. obs.). However, according to the phylogeographic analysis of Lázaro et al. (2009) this population is molecularly identical to the Pogradec population and therefore should be assigned also to D. superioris. It is noteworthy that the Voskopojë locality is outside of the Ohrid basin and therefore signals a wider distribution of $D$. superioris.

That Kenk (1978) identified his Dugesia material from Ohrid (NMNH 55294) as $D$. gonocephala is hardly surprising in view of the fact that at that time many European populations were assigned to $D$. gonocephala sensu lato. The precise anatomy of $D$. gonocephala sensu stricto was only resolved by De Vries and Ball (1980) and De Vries (1984a, 1986). A comparison with Kenk's specimen quickly learns that this animal does not conform to D. gonocephala because it does not exhibit the muscular ridges, the elongated penis papilla, or the two penial folds (cf. De Vries and Ball 1980, De Vries 1984a). In the presence of a small dorsal penial fold and a central ejaculatory duct the animal resembles Dugesia benazzii Lepori, 1951, D. elegans De Vries, 1984, D. taurocaucasica (Livanov, 1951) and D. effusa, the latter recently described from the Greek island Chios (Sluys et al. in prep.). Dugesia benazzii from Corsica and Sardinia is characterized by a pointed diaphragm and a penial fold, the position of which is variable but which is usually located dorsally; the size of the penial fold is also variable (Lepori 1951, De Vries 1984b). In D. benazzii ectal reinforcement is restricted to the region of the oviducal openings, the latter being symmetrically arranged. In contrast, in the NMNH 55294 specimen the oviducts open asymmetricaly into the bursal canal, while the ectal reinforcement extends further on the bursal canal.

Dugesia elegans from Rhodes differs from NMNH 55294 in the presence of a much larger seminal vesicle, a stubbier diaphragm, and the situation that its bursal canal epithelium is infranucleated (De Vries 1984a).

The penial fold of D. taurocaucasica is considerably larger than the one in NMNH 55294 , while the fold is also traversed by the abundant secretion of cyanophilic glands, which discharge through the lining epithelium of the penial fold. Furthermore, in $D$. taurocaucasica the ectal reinforcement layer on the bursal canal extends for a considerable distance towards the copulatory bursa (Porfirjeva and Dyganova 1987).

The species Dugesia effusa differs from NMNH 55294 in the presence of a short, valve-like diaphragm, a large intrabulbar seminal vesicle, a highly glandular penis papilla, and symmetrical oviducal openings into the bursal canal.

Therefore, the Dugesia specimen NMNH 55294 may well represent a new species. However, on the basis of only the presently available material we refrain from describing it as new. Furthermore, the asymmetrical openings of the vasa deferentia into the 
seminal vesicle of this animal represents a highly unusual condition for a species of Dugesia and needs to be checked on additional material.

Present data support Stanković' (1960) suggestion that two faunistic complexes may be distinguished in the Lake Ohrid region, viz. (1) lacustrine endemic forms and (2) inhabitants of other waters outside of the lake with a wider distributional range. In the Ohrid region it is evident that there is a very low degree of exchange between the lacustrine endemic fauna and the non-endemic fauna. Further, the distribution of triclads in the Lake Ohrid area supports the situation for the lake's fauna in general, namely that endemism occurs at different spatial scales, ranging from species endemic to some parts of the lake to species endemic to the whole Ohrid basin (Albrecht and Wilke 2008).

\section{Acknowledgements}

This research was funded in part by the Regione Autonoma Sardegna (CRP-60215 "Conservazione e valorizzazione delle grotte sarde: biodiversità e ruolo socio-economico-culturale). G.A.S. acknowledges financial support by the "Fondazione Banco di Sardegna" and SYNTHESYS, a programme of the European Commission under the 7th Research and Technological Development Framework Programme (grant number: NL-TAF 2772). Completion of the manuscript was made possible by a grant from the Naturalis Biodiversity Center to R. Sluys. Dr. Jon Norenburg (National Museum of Natural History (NMNH), Washington, USA) kindly sent on loan the Dugesia specimen collected by R. Kenk. We thank Prof. G. Corso for her kind support. G.A.S. is grateful to Prof. M. Pala for her financial support in memory of her husband Prof. N.G. Lepori. R.S. thanks Prof. Dr. M. Kawakatsu for providing a copy of a cited publication.

\section{References}

Albrecht C, Wilke T (2008) Ancient Lake Ohrid: biodiversity and evolution. Hydrobiologia 615: 103-140. doi: 10.1007/s10750-008-9558-y

Arndt W (1938) Spongiologische Unterschungen am Ochridasee. Archiv für Hydrobiologie 34: 48-80.

Ball IR (1970) Freshwater Triclads (Turbellaria, Tricladida) from the Oriental Region. Zoological Journal of the Linnean Society 49: 271-294. doi: 10.1111/j.1096-3642.1970. tb00742.x

Banchetti R, Del Papa R (1971) Descrizione della planaria Dugesia lanzai, n. sp. del Kenya (Africa). Atti della Società Toscana di Scienze Naturali 78: 20-35.

Benazzi M (1946) Sopra una nuova planaria d'acqua dolce. Archivio Zoologico Italiano 31: 93-102.

Batistoni R, Rossi L, Salvetti A, Deri P (1999) A molecular cytogenetic comparison of planarians from the 'Dugesia gonocephala group' (Platyhelminthes, Tricladida). Italian Journal of Zoology 66: 239-244. doi: 10.1080/11250009909356261 
Benazzi M, Banchetti R (1972) Descrizione di Dugesia biblica, nuova microspecie del "gruppo Dugesia gonocephala" trovata nel fiume Giordano (Israele). Atti della Società Toscana di Scienze Naturali 79: 83-91.

Benazzi M, Benazzi Lentati G (1976) Platyhelminthes. In: John B (Ed) Animal cytogenetics. Gebrüder Borntraeger, Berlin-Stuttgart, Vol I, 1-182.

De Beauchamp P (1952) Sur les Dugesia (Turbellariés Triclades) d'Afrique tropicale et de Madagascar. Bulletin de la Société Zoologique de France 77: 362-370.

De Beauchamp P (1959) Triclades Paludicoles d'Afganistan (Contribution à l'Étude de la Faune d'Afganistan, I). Kungliga Fysiografiska Sällskapets i Lund Förhandlingar 29: 27-43.

Deri P, Colognato R, Rossi L, Salvetti A, Batistoni R (1999) A karyological study on populations of Dugesia gonocephala s.l. (Turbellaria, Tricladida). Italian Journal of Zoology 66: 245-253. doi: 10.1080/11250009909356262

De Vries EJ, Ball IR (1980) On Dugesia gonocephala from Western Europe. Bijdragen tot de Dierkunde 50: 342-350.

De Vries EJ (1984a) On the species of the Dugesia gonocephala group (Platyheminthes, Turbellaria, Tricladida) from Greece. Bijdragen tot de Dierkunde 54: 101-126.

De Vries EJ (1984b) On the taxonomic status of Planaria torva from Corsica (Turbellaria, Tricladida, Paludicola). Mitteilungen aus dem Zoologischen Museum in Berlin 60: 17-21.

De Vries EJ (1986) On the taxonomic status of Dugesia gonocephala and Dugesia subtentaculata (Turbellaria, Tricladida, Paludicola). Journal of Zoology, London 209: 43-59. doi: 10.1111/j.1469-7998.1986.tb03565.x

De Vries EJ (1988a) Further contributions to the taxonomy and biogeography of the subgenus Dugesia (Platyhelminthes: Tricladida: Paludicola) in the Mediterranean region and the Middle East. Israel Journal of Zoology 35: 109-136.

De Vries EJ (1988b) A synopsis of the nominal species of the subgenus Dugesia (Platyhelminthes, Tricladida, Paludicola) from Africa and Madagascar. Zoological Journal of the Linnean Society 92: 345-382. doi: 10.1111/j.1096-3642.1988.tb01729.x

Harrath AH, Sluys R, Aldahmash W, Al-Razaki A, Alwasel S (2013) Reproductive strategies, karyology, parasites, and taxonomic status of Dugesia populations from Yemen (Platyhelminthes, Tricladida, Dugesiidae). Zoological Science 30: 502-508. doi: 10.2108/zsj.30.502

Ichikawa A, Kawakatsu M (1964) A new freshwater planarian, Dugesia japonica, commonly but erroneously known as Dugesia gonocephala (Dugès). Annotationes Zoologicae Japonenses 36: $102-107$.

Ijima I (1884) Untersuchungen über den Bau und die Entwicklungsgeschichte der Süsawasser-Dendrocoelen (Tricladen). Zeitschrift für wissenschaftliche Zoologie 40: 359-464.

Kaburaki T (1918) Freshwater Triclads from the Basin of the Inlé Lake. Records of the Indian Museum 14: 187-194.

Kaburaki T (1925) Planarians from the Andamans. Records of the Indian Museum 27: 29-32. Kawakatsu M (1969) Report on Freshwater Planaria from India. Annotationes Zoologicae Japonenses 42: 210-215. 
Kawakatsu M (1973) Report on Freshwater Planaria from Indonesia (Sumatra and Java). Contributions from the Biological Laboratory, Kyoto University 24: 87-103.

Kawakatsu M (1976) The Freshwater Planarians from New Guinea and Malaya. Bulletin of the National Museum, Tokyo 2: 143-152.

Kawakatsu M, Mitchell RW (1989) Dugesia deharvengi sp. n., a new troglobitic freshwater planarian from Tham Kubio Cave, Thailand (Turbellaria; Tricladida; Paludicola). Bulletin of the Biogeographical Society of Japan 44: 175-182.

Kawakatsu M, Mitchell RW (1995) Two new freshwater cavernicolous planarians (Turbellaria, Tricladida, Paludicola) from Sulawesi (Celebes), Indonesia. Special Bulletin of the Japanese Society of Coleopterology 4: 81-103.

Kawakatsu M, Oki I, Tamura S, Yamayoshi T (1985) Reexamination of freshwater planarians found in tanks of tropical fishes in Japan, with a description of a new species, Dugesia austroasiatica sp. n. (Turbellaria; Tricladida; Paludicola). Bulletin of the Biogeographical Society of Japan 40: 1-19.

Kawakatsu M, Tamura S, Yamayoshi T, Oki I (1980) The Freshwater Planaria from Thailand and South India. Annotationes Zoologicae Japonenses 42: 210-215.

Kawakatsu M, Oki I, Tamura S, Yamayoshi T, Aditya AK (1983) A new freshwater planarian from West Bengal. Bulletin of the Biogeographical Society of Japan 38: 1-10.

Kenk R (1978) The planarians (Turbellaria: Tricladida Paludicola) of the Lake Ohrid in Macedonia. Smithsonian Contributions to Zoology 280: 1-56. doi: 10.5479/ si.00810282.280

Lázaro EM, Sluys R, Pala M, Stocchino GA, Bagunà J, Riutort M (2009) Molecular barcoding and phylogeography of sexual and asexual freshwater planarians of the genus Dugesia in the Western Mediterranean (Platyhelminthes, Tricladida, Dugesiidae). Molecular Phylogenetics and Evolution 52: 835-845. doi: 10.1016/j.ympev.2009.04.022

Lepori NG (1948) Descrizione di Dugesia sicula, nuova specie di Triclade d'acqua dolce dei dintorni di Catania. Archivio Zoologico Italiano 33: 461-472.

Lepori NG (1951) Sulle caratteristiche morfologiche e sulla posizione sistematica della planaria di Sardegna e Corsica già ascritta a Dugesia gonocephala (Dugès). Atti Società Toscana di Scienze Naturali 58 (B): 1-22.

Livanov NA (1951) Planarii Kopet-Daga i blizkie vidy Kryma, Kavkaza i Zakavkaz’ia. Trudy Murgabskoı̆ Gidrobiologicheskoŭ Stantsii 1: 103-114.

Marcus E (1953) Turbellaria Tricladida. In: Institut des Parcs Nationaux du Congo Belge, Exploration du Parc National de l'Upemba, Mission G.F. de Witte, 1946-1949, 21: 1-62.

Mrázek A (1904) Ergebnisse einer von Dr. Al. Mrázek im J. 1902 nach Montenegro unternommenen Sammelreise. Věstnik královské České Společnosti Náuk, Třída mathematicko-přirodovědecká, for 1903 (15).

Müller OF (1774) Vermium terrestrium et fluviatilium, seu Animalium infusorium, helminthicorum, et testaceorum, non marinorum, succincta historia. Hauniae \& Lipsiae. 1(2).

Neppi V (1904) Über einige exotische Turbellarien. Zoologische Jahrbücher, Abteilung für Systematik Geographie und Biologie der Tiere 21: 303-326. 
Pala M (1993) Correlation between chromosome complement and reproduction in a population of a freshwater triclad. In: Animal Biology. $39^{\text {th }}$ Annual Meeting of the Italian Embryology Group, Alghero (Italy), June 1993. 2: 131.

Pala M, Casu S, Vacca RA (1981) Dugesia hepta, nuova specie di planaria d'acqua dolce di Sardegna appartenente alla superspecie Dugesia gonocephala (Dugès) (Turbellaria, Tricladida). Bollettino della Società Sarda di Scienze Naturali 20: 97-107.

Pala M, Stocchino GA, Corso G, Casu S (2000) A new species of freshwater planarian belonging to the genus Dugesia (Platyhelminthes, Tricladida) from Sardinia. Italian Journal of Zoology 67: 379-383. doi: 10.1080/11250000009356343

Porfirjeva NA (1958) Planarii Kavkaza [Planarians of the Caucasus]. Trudy Obshchestva Estestvoispytateler pri Kazanskom gosudarstvennom Universitete 62: 39-89. [in Russian]

Porfirjeva NA, Dyganova RY (1987) Planarii europeiskoi ciasti SSSR [Planarians of the European part of the USSR - Morphology, Systematics, Distribution]. University of Kazan. 188 pp. [in Russian]

Reisinger E (1960) Vitale Nervenfärbungen bei Plathelminthen und ihre Abhängigkeit vom physiologischen Zustand des Organismus. Zeitschrift für wissenschaftliche Zoologie 164: 271-293.

Ribas M (1990) Cariologia, sistematica i biogeografia de les Planaries d'aigues dolces al Paisos Catalans. Barcelona: PhD thesis, Barcelona, Spain: University of Barcelona.

Schmidt O (1861) Ueber Planaria torva Autorum. Zeitschrift für wissenschaftliche Zoologie 11: 89-94.

Sluys R, Kawakatsu M, Winsor L (1998) The genus Dugesia in Australia, with its phylogenetic analysis and historical biogeography (Platyhelminthes, Tricladida, Dugesiidae). Zoologica Scripta 27: 273-289. doi: 10.1111/j.1463-6409.1998.tb00461.x

Sluys R, Solà E, Gritzalis K, Vila-Farré M, Mateos E, Riutort M (in prep) Integrative delineation of species of Mediterranean freshwater planarians (Platyhelminthes, Tricladida, Dugesiidae).

Solà E, Sluys R, Gritzalis K, Riutort M (2013) Fluvial basin history in the northeastern Mediterranean underlies dispersal and speciation patterns in the genus Dugesia (Platyhelminthes, Tricladida, Dugesiidae). Molecular Phylogenetics and Evolution 66: 877-888. doi: 10.1016/j.ympev.2012.11.010

Stanković S (1938) Novi prilozi poznavanju endemičnih triklada Ohridskog jezera (Nouvelle contribution à la connaissance des Triclades endémiques du lac d'Ohrid). Glasnik Skopskog Naučnog Drušva 18: 1-12 [in Serbo-Croatian]

Stanković S (1960) The Balkan lake Ohrid and its living world. Uitgeverij Dr Junk W, Den Haag, 357 pp.

Stanković S (1969) Turbellariés Triclades endémiques nouveaux du lac d'Ohrid. Archiv für Hydrobiologie 65: 413-435.

Stanković S, Komárek J (1927) Die Süsswasser-Tricladen des Westbalkans und die zoogeographischen Probleme dieser Gegend. Zoologische Jahrbücher, Abteilung für Systematik 53: 591-674. 
Stocchino GA, Corso G, Manconi R, Pala M (2002) African planarians: Dugesia aethiopica sp. n. (Platyhelminthes, Tricladida) from Lake Tana (NW Ethiopia). Italian Journal of Zoology 69: 45-51. doi: 10.1080/11250000209356437

Stocchino GA, Corso G, Manconi R, Casu S, Pala M (2005) Endemic freshwater planarians of Sardinia: Redescription of Dugesia hepta (Platyhelminthes, Tricladida) with a comparison of the Mediterranean species of the genus. Journal of Natural History 39: 1947-1960. doi: 10.1080/00222930500060025

Sywula T, Krstanovski Z, Biala A, Wysocka A, Kilikowska A, Sell J (2006) Phylogenetic position of Dendrocoelum lacteum (Tricladida) from the Balkan Lake Ohrid evidenced by allozyme data. Biochemical Systematics and Ecology 34: 212-218. doi: 10.1016/j.bse.2005.11.003 